\title{
Analysis of Cost Sharing on the Satisfaction of NHI Patients Not Contribution Beneficiaries (Case Study of Passo Hative Hospital in Ambon City)
}

\author{
Yoki Stefanus ${ }^{1}$, Darmawansyah ${ }^{2}$, Muhammad Alwy Arifin ${ }^{2}$, Indar ${ }^{2}$, Syamsuar Manyullei $^{3}$, Ansariadi $^{4}$, Dian \\ Saputra Marzuki \\ ${ }^{1}$ Magister Program Departement of Health Administration and Policy, Public Health Hasanuddin University, \\ ${ }^{2}$ Departement of Health Administration and Policy, Public Health Hasanuddin University, ${ }^{3}$ Departement of \\ Environmental Health, Public Health Hasanuddin University, ${ }^{4}$ Departement Epidemiology, Public Health \\ Hasanuddin University
}

\begin{abstract}
Cost Sharing is a fee payable by the patient participant of the social insurance administration Organization because it gets health services in the hospital which is derived from the reduction in tariffs with the amount of costs incurred by the social insurance administration Organization. Analyse the additional costs that the Passo Hative Hospital has done to patient satisfaction. This type of research is quantitative research by using a cross-sectional design approach. The population in this study is all the patients of the national health care insurance not the recipient of dues lwho are being treated at hospitalisation in the Passo Hative Hospital in Ambon City with the last one month visit was 150 patients. The sampling techniques in this study are accidental sampling. The results showed there was an additional cost relationship moving the treatment class to patient satisfaction $(\mathrm{P}=0.001)$. There is a relationship of medical services additional costs to patient satisfaction $(\mathrm{P}=0,016)$ and there is a connection to the additional cost of medication to patient satisfaction $(\mathrm{P}=0,000)$ of the hospital as a service provider of the social insurance administration Organization in order to be more observant to see the cause of the users of the social insurance administration Organization to change the treatment class of the care and fulfill and complement medical services and medicines that are the right of the patient according to the social insurance administration Organization.
\end{abstract}

Keywords: Cost Sharing, Moving classes, medical services, medication, hospital

\section{Introduction}

Universal health protection or globally known as the term Universal Health Coverage (UHC) aims to provide health care insurance for all residents (health for all). It is necessary to obtain sufficient attention for all stakeholders to ensure better quality of health services and can be achieved in 2030 as a deal for all UN Member States ${ }^{1}$.

Strategic purchasing is an activity that includes the provider's relationship to information, such as provider

\footnotetext{
Correspondence Author:

Yoki Stefanus

E-mail: devenstefanus@gmail.com
}

performance or population health needs, aligning funding and revenue to achieve increased efficiency, accountability, service delivery, and equity ${ }^{2}$. The additional cost is the cost of medicines that do not go into the list of the price of the drug, medical services and occupy a treatment class that does not comply with its goals ${ }^{3}$.

Outline, the additional costs paid by the participant of the social insurance administration Organization in hospital may be grouped in two, which is Cost Sharing allowed and Cost Sharing not allowed. Cost Sharing are allowed, consisting of a fee due to the grade-up of the care class that is the right (according to presidential decree No. 12/2013 on National Health Insurance Article 24 and PERMENKES RI number $71 / 2013$ on health 
services on National health insurance) and costs due including health services that are not guaranteed. While the Cost Sharing not allowed, that is all that includes the guaranteed health service ${ }^{4}$.

Data social insurance administration Organization in Ambon Branch said from 215 complaints against advanced health facilities received in 2018, 69 cases (32\%) cost sharing by the advanced healthcare facilities. While the data of the Case-Mix team of the Passo Hative Hospital, in 2018 there are 12 reports of patient complaints regarding the burden of additional charges. To support the fact above, in research that has been conducted, there were 37 of 200 respondents of NHI patients experiencing cost sharing from healthcare providers.

Although the cost sharing may not be made, this issue persists. This can be due to many factors that are quite complex and intertwined. However, there are cost sharing for the participants of the social insurance administration Organization, especially the additional costs that are not allowed, can be due to three aspects of the cause, namely the participant aspect, the hospital aspect and INA Cbg'S aspect itself ${ }^{4}$. The research aims to analyse the additional costs that the Passo Hative hospital has made against patient satisfaction .

\section{Materials and Methods}

The type of research used is quantitative research with the design of Cross-Sectional studies. The population in this study is all the patients of the national health care insurance not the recipient of dues who are being treated at hospitalisation in the Passo Hative Hospital in Ambon City with the last one month visit was 150 patients. The sampling techniques in this study are accidental sampling. Data collection is obtained through a live interview using a questionnaire.

\section{Result}

According to table 1, it is known that the number of respondents who are more than $30-60$ years of age is 51 people (46.8\%), while the least respondents are in the category age of $>60$ Year 8 people $(7.3 \%)$. According to gender, the number of male respondents was more than 56 people $(51.4 \%)$, while female respondents were 53 people (48.6\%). Based on NHI class the number of respondents who have the right grade II class is more than 46 people $(42.2 \%)$, while the right grade NHI respondents are the fewest class I is 24 people $(22.0 \%)$.

Table 1. Distribution of Respondents Based on Characteristics of Respondents at Hative Passo Hospital in 2020

\begin{tabular}{|c|c|c|}
\hline Characteristics of Respondents & Amount (n) & Percent (\%) \\
\hline $\begin{array}{l}\text { h. } \\
<30 \\
30-60 \\
>60\end{array}$ & $\begin{array}{l}50 \\
51 \\
8\end{array}$ & $\begin{array}{l}45.9 \\
46.8 \\
7.3\end{array}$ \\
\hline Total & 109 & 100 \\
\hline $\begin{array}{l}\text { i. } \quad \text { Gender } \\
\text { Male } \\
\text { Girl }\end{array}$ & $\begin{array}{l}56 \\
53\end{array}$ & $\begin{array}{l}51.4 \\
48.6\end{array}$ \\
\hline Total & 109 & 100 \\
\hline $\begin{array}{l}\mathrm{j} . \quad \text { JKN class } \\
\text { Grade } 3 \\
\text { Grade 2 } \\
\text { Class 1 }\end{array}$ & $\begin{array}{l}39 \\
46 \\
24\end{array}$ & $\begin{array}{l}35.8 \\
42.2 \\
22\end{array}$ \\
\hline Total & 109 & 100 \\
\hline
\end{tabular}


According to table 2, shows that respondents did not charge an cost sharing when moving treatment classes by 87 people (79.8\%), while respondents who issued 22 people $(20.2 \%)$. Based on the cost sharing of medical services showed that respondents did not spend an cost sharing for medical services as much as 99 people (90.8\%), while respondents who spent 10 cost sharing
$(9.2 \%)$. Based on the cost sharing of the drug service showed that respondents who did not spend additional costs for the drug service as much as 36 people (33\%), while respondents who issued an cost sharing of 73 people $(67 \%)$. Based on the satisfaction of the patient showed that the respondents were satisfied with the

Table 2. Distribution of Respondents Based on cost sharing at Hative Passo Hospital 2020

\begin{tabular}{|c|c|c|}
\hline Research variable & Amount (n) & Percent (\%) \\
\hline $\begin{array}{l}\text { a. Cost sharing of Moving Care Class } \\
\text { There is no } \\
\text { There is }\end{array}$ & $\begin{array}{l}87 \\
22\end{array}$ & $\begin{array}{l}79.8 \\
20.2\end{array}$ \\
\hline Total & 109 & 100 \\
\hline $\begin{array}{l}\text { b. Cost sharing of Medical Services } \\
\text { There is no } \\
\text { There is }\end{array}$ & $\begin{array}{l}99 \\
10\end{array}$ & $\begin{array}{l}90.8 \\
9.2\end{array}$ \\
\hline Total & 109 & 100 \\
\hline $\begin{array}{l}\text { c. Cost sharing of Drug Services } \\
\text { There is no } \\
\text { There is }\end{array}$ & $\begin{array}{l}36 \\
73\end{array}$ & $\begin{array}{l}33 \\
67\end{array}$ \\
\hline Total & 109 & 100 \\
\hline $\begin{array}{l}\text { d. Patient Satisfaction } \\
\text { Satisfied } \\
\text { Less satisfied }\end{array}$ & $\begin{array}{l}54 \\
55\end{array}$ & $\begin{array}{l}49.5 \\
50.5\end{array}$ \\
\hline Total & 109 & 100 \\
\hline
\end{tabular}


Table 3. The Relationship between cost sharing and Satisfaction of NHI Patients Not Recipients of Contribution Aid at Hative Passo Hospital in 2020

\begin{tabular}{|c|c|c|c|c|c|c|c|}
\hline \multirow{3}{*}{ Research variable } & \multicolumn{4}{|c|}{ Satisfaction } & \multirow{2}{*}{\multicolumn{2}{|c|}{ total }} & \multirow{3}{*}{ p } \\
\hline & \multicolumn{2}{|c|}{ Satisfied } & \multicolumn{2}{|c|}{ Less satisfied } & & & \\
\hline & $\mathbf{n}$ & $\%$ & $\mathrm{n}$ & $\%$ & $\mathbf{N}$ & $\%$ & \\
\hline $\begin{array}{l}\text { Cost sharing of Trans } \\
\text { There is no } \\
\text { There is }\end{array}$ & $\begin{array}{l}50 \\
4\end{array}$ & $\begin{array}{l}45.9 \\
3,7\end{array}$ & $\begin{array}{l}37 \\
18\end{array}$ & $\begin{array}{l}33.9 \\
16.5\end{array}$ & $\begin{array}{l}87 \\
22\end{array}$ & $\begin{array}{l}100 \\
100\end{array}$ & .001 \\
\hline Total & 54 & 49.6 & 55 & 50.4 & 109 & 100 & \\
\hline $\begin{array}{l}\text { Cost sharing of medi } \\
\text { There is no } \\
\text { There is }\end{array}$ & $\begin{array}{l}53 \\
1\end{array}$ & $\begin{array}{l}48.6 \\
0.9\end{array}$ & $\begin{array}{l}46 \\
9\end{array}$ & $\begin{array}{l}42.2 \\
8.3\end{array}$ & $\begin{array}{l}99 \\
10\end{array}$ & $\begin{array}{l}100 \\
100\end{array}$ & 0.016 \\
\hline Total & 54 & 49.5 & 55 & 50.5 & 109 & 100 & \\
\hline $\begin{array}{l}\text { Cost sharing of drug } \\
\text { There is no } \\
\text { There is }\end{array}$ & $\begin{array}{l}28 \\
26\end{array}$ & $\begin{array}{l}25.7 \\
239\end{array}$ & $\begin{array}{l}8 \\
47\end{array}$ & $\begin{array}{l}7.3 \\
43.1\end{array}$ & $\begin{array}{l}36 \\
73\end{array}$ & $\begin{array}{l}100 \\
100\end{array}$ & 0,000 \\
\hline Total & 54 & 49.6 & 55 & 40.4 & 109 & 100 & \\
\hline
\end{tabular}

Table 3 above can be noted that the number of respondents who do not spend cost sharing when moving treatment room classes or not moving classes of care and feel quite satisfied as much as 50 people (45.9\%) And respondents who felt dissatisfied as much as 37 people $(33.9 \%)$. While respondents who spend cost sharing when moving treatment room classes but still feel satisfied as much as 4 people (3.7\%) And respondents who were dissatisfied as much as 18 people (16.5\%). Chi Square Statistical test results obtained a value of $\mathrm{P}=0.001$ or a value of $\mathrm{P}<0.05$. Thus Ho was rejected and Ha was accepted. This indicates that there is an additional cost incurred by the patient when moving the class of treatment room enough to affect patient satisfaction in the Passo Hative Hospital of Ambon City.
Based on the cost sharing of medical services shows that the number of respondents who did not spend an cost sharing for medical treatment or service and felt quite satisfied as much as 53 people (48.6\%) And respondents who felt dissatisfied as much as 46 people $(42.2 \%)$. While the respondent who issued an cost sharing for medical treatment or service but still satisfied as much as 1 person $(0.9 \%)$ And respondents who felt less than 9 people (8.3\%). Test result Statistics Fisher's Exact Test obtained the value $\mathrm{P}=0,016$ or the value $\mathrm{p}<0.05$. Thus Ho was rejected and Ha was accepted. This indicates that there is an cost sharing incurred by the patient when obtaining treatment or other medical services to adequately affect patient satisfaction in the Passo Hative Hospital in Ambon. 
Based on the cost sharing of the drug indicates that the number of respondents who did not spend cost sharing for the service or the purchase of the drug and felt enough satisfied as much as 28 people $(25.7 \%)$ And respondents who felt less than 8 people $(7.3 \%)$. While respondents who issued cost sharing for the service or the purchase of the drug but remained satisfied as much as 26 people (23.9\%) And respondents who felt dissatisfied as much as 47 people (43.1\%). Chi Square Statistical test results obtained the value $\mathrm{P}=0,000$ or the value $p<0.05$. Thus Ho was rejected and Ha was accepted. This indicates that the presence of cost sharing incurred by the patient for the ministry or purchase of the drug adequately affects patient satisfaction in the Passo Hative Hospital in Ambon City.

\section{Discussion}

\section{Cost sharing of moving treatment classes to patient satisfaction}

Patients who are up in the treatment class then the cost of a fee is the difference between the requested class fee minus the class fee on his right. Participants may also decide to board the treatment class as a result of a room with full-care class privileges. This could happen when the bed capacity and the need for the existing class are not balanced in a hospital. The number of requests is not always balanced by the availability of appropriate inpatient classrooms.

Customer satisfaction is the level of a person's feelings after comparing the perceived performance (result) compared to his expectations. The measurement of patient satisfaction is much done but difficult to do because of its subjective nature. When the patient decides to board the class, the patient has an expectation of the service and the amount of fees to be paid. When expected expectations do not match the reality, there is dissatisfaction

In the era of national health insurance, the participants can be able to improve the treatment class when hospitalized. Before deciding on choices such as boarding classes, participants also thought about other possibilities such as costly fees, healthcare services and the economic opportunities gained from their choice. The option to move the class can be seen on the number of respondents who moved to the class of 22 people
$(20.2 \%)$. This is relevant to the compulsion of paying. This condition occurs in the state of the inpatient class with full rights. If the treatment class does not meet the expectation and ability of the patient, but the need for health status requires the patient to choose and pay the service $^{5}$. When the patient and his family choose an inpatient class, of course there are various factors that are considered as basic considering benefit and cost. It is in accordance with the theory of rational choice.

\section{Cost sharing of Medical services to patient satisfaction}

Health care is any effort that is held alone or jointly in an organization to maintain and improve health, prevent and cure diseases and restore the health of individuals, families, groups and communities. The weight or light of hospitalized patients is difficult to predict, so the hospital cannot have patients treated with certain reasons ${ }^{[3]}$. Due to the heavy weight of disease hospitalized, the heavier the disease suffered by one, the more complex the medical examinations/actions will be performed. This situation poses another consequence of higher cost expenditure. In addition, the light weight of the disease condition provides a different contribution to the amount of unit cost to be spent per day

The results of the study Dassi \& Hardi (2019) showed that the participants of social insurance administration Organization so far have more financing assistance in terms of inpatient rates, while drugs and medical actions are still not adequate., because for certain medical action the amount (RP) to be paid by the patient is much greater than that borne by PT. social insurance administration Organization. Cost Sharing costs incurred by the patient in terms of the type of action of RS health officers as much as Rp. $422,000^{3}$

\section{Cost sharing of drug services to patient satisfaction}

Drug service is the provision of medicines outside the standard medicine included in the hospital package, which is required for health care in accordance with medical indications and with a ceiling list of drug prices used for participants and their families by the social insurance administration Organization according to the decree of the Minister of Health. As for the medicines included in the ceiling list of drug prices is not a generic 
drug, but the medication needed can be administered at a price that meets a specific ceiling list. The selection of drugs conducted by pharmacology and clinical experts, and also conducted analysis of the price aspects of making ceiling list of drug prices which refers to the list of national Essential medicines that have been compiled by the government. This is because the medicines in the list of national Essential medicines are the most needed and absolutely necessary medicines to be held. Some types of drugs that enter the list of national Essential medicines ranging from antibiotics, anti-inflimasi, anti-depressants, antihypertensive, anti-fungal, asthma medication, stomach ulcers to skin medications. The research conducted by Nita et al, 2020 shows the patient satisfaction of the pharmacy ministry in the hospital by $90.9 \%$ lower than the pharmacy ministry in the Public health center by $96.6 \%{ }^{6}$.

Meanwhile, in research conducted by Prastina Prayogi (2018) on the policy study of National Health Insurance Program in Sidoarjo District, stating that with the process that occurred in the implementation of the implementation to several hospitals or health facilities, still shows the service provided has not been fulfilled. There are patients who are denied medication, and there are also additional costs for the drug. It concluded that the lack of response responses between officers on patients, lack of socialization provided by policy organizers and policy executor in terms of information, inspection services and the placement of additional costs to be paid alone 7-12 $^{72}$

\section{Conclusion}

The study concluded that there was an relationship cost sharing moving treatment classes to patient satisfaction $(\mathrm{P}=0.001)$. There is a relationship cost sharing of medical services to patient satisfaction ( $\mathrm{P}=$ $0,016)$ and there is a relationship cost sharing of drug service to patient satisfaction ( $\mathrm{P}=0,000)$ of Passo Hative hospital as social insurance administration Organization service provider to be more observant to see the cause of social insurance administration Organization users to change treatment class from care class that should be the right, and fulfill and complement medical services and medicines that.

\section{Sourve of Funding : Self}

\section{Conflict of Ineterst : Nil}

Ethical Clearance : Obtained from the University Ethical clearance committee

\section{References}

1. Palutturi, S., Politik Kesehatan Di Indoneisa. 2019, Yogyakarta: Pustaka Pelajar.

2. Feldhaus, I. and I. Mathauer, Effects of mixed provider payment systems and aligned cost sharing practices on expenditure growth management, efficiency, and equity: a structured review of the literature. BMC health services research, 2018. 18(1): p. 996.

3. Dassi, M. and H. Kalmi, Analisis Cost Sharing (Biaya Tambahan) Pasien BPJS Di Rumah Sakit Pasar Wajo Buton Provinsi Sulawesi Tenggara. Jurnal Komunitas Kesehatan Masyarakat, 2019. 1(1): p. 40-47.

4. Gultom, N.B., C. Jaya, and A. Atmiroseva, Survei Pendahuluan Biaya Tambahan Peserta BPJS Kesehatan pada Rumah Sakit Faskes BPJS Kesehatan di Jabodetabek. Jurnal Kebijakan Kesehatan Indonesia: JKKI, 2015. 4(1): p. 3-10.

5. Palupi, J.K.N., V. Wardhani, and S. Andarini, Determinan Pilihan Naik Kelas Perawatan Rumah Sakit dari Kelas I ke Kelas VIP. Jurnal Kebijakan Kesehatan Indonesia: JKKI, 2016. 5(4): p. 176183.

6. Prihartini, N., et al., Kepuasan Pasien Rawat Jalan terhadap Pelayanan Kefarmasian di Rumah Sakit dan Puskesmas di 11 Provinsi di Indonesia. Jurnal Kefarmasian Indonesia, 2020: p. 42-49.

7. Prayogi, P., Relasi Pemerintah Dan Rumah Sakit Swasta Dalam Kebijakan Program Jaminan Kesehatan Nasional-Penerima Bantuan Iuran Di Sidoarjo. 2018, Universitas Airlangga: Surabaya.

8. Anwar Mallongi, Ruslan La Ane and Agus Bintara Birawida. Ecological risks of contaminated lead and the potential health risks among school children in Makassar coastal area, Indonesia. J. Environ. Sci. Technol., 2017; 10: 283-289.

9. Wardana et al 2019 IOP Conf. Ser.: Earth Environ. Sci. 235012101

10. AB Birawida, M.Selomo and A. Mallongi, Potential hazards from hygiene, sanitation and bacterium of refill drinking water at Barrang Lompo, IOP Conference Series: Earth and Environmental 
Science, vol: 157, issue : 1, 2018-06-1, Conference Proceeding.

11. Rosmala Nur, Siti Ika Fitrasyah, Anwar Mallongi, Women's Reactions and Health Disorders Caused by Abuse During the Pregnancy-Postpartum Period. Medico-legal Update, January-March 2020, Vol.20, No. 1
12. Muhith A, Winarti E, Perdana SSI, Haryuni S, Rahayu KIN, Mallongi A. Internal Locus of Control as a Driving Factor of Early Detaction Behavior of Servical Cancer by Inspection Visual of Acetic Acid Method. Open Access Maced J Med Sci. 2020Apr 20; 8(E):113-116. https:// doi. org/10.3889/oamjms.2020.4341 